Revue d'histoire de l'Amérique française

REVUE D.HISTOIRE DE L'AMÉRIQUE FRANÇAISE

\title{
L'orientation des recherches historiques à Louisbourg
}

\section{Henri-Paul Thibault}

Volume 24, numéro 3, décembre 1970

URI : https://id.erudit.org/iderudit/302992ar

DOI : https://doi.org/10.7202/302992ar

Aller au sommaire du numéro

Éditeur(s)

Institut d'histoire de l'Amérique française

ISSN

0035-2357 (imprimé)

1492-1383 (numérique)

Découvrir la revue

Citer cette note

Thibault, H.-P. (1970). L'orientation des recherches historiques à Louisbourg. Revue d'histoire de l'Amérique française, 24(3), 408-412.

https://doi.org/10.7202/302992ar d'utilisation que vous pouvez consulter en ligne.

https://apropos.erudit.org/fr/usagers/politique-dutilisation/ 
L'ORIENTATION DES RECHERCHES HISTORIQUES À LOUISBOURG

\section{Henri-Paul Thibault \\ Département d'histoire \\ Forteresse de Louisbourg}

En 1962, le gouvernement fédéral entreprenait la reconstruction d'une partie de la ville fortifiée de Louisbourg.

On sait qu'après le traité d'Utrecht de 1713, Louisbourg devint un grand port de pêche et un important centre militaire et commercial tant pour la France que pour ses colonies d'Amérique. En 1745 et en 1758, les Anglais s'emparent de la place et déportent la population. Les fortifications sont démolies en 1760 et huit ans plus tard, le transfert de la garnison à Halifax amorce l'abandon graduel de la ville.

Le projet actuel de reconstruction a nécessité plusieurs études historiques. A cet effet, un centre de recherche a été 
créé. Les rapports rédigés au département d'histoire ont un caractère très spécialisé et sont parfois d'inégale valeur, à cause du temps disponible et des exigences de la reconstruction. Toutefois, ils peuvent intéresser les chercheurs qui désirent approfondir certains aspects de l'histoire de la Nouvelle-France tels la civilisation matérielle, l'architecture civile, l'art militaire, la place de l'Ile Royale dans les relations nord-Atlantique, etc.

Des études plus complètes seront terminées sous peu et traiteront de l'architecture et du costume civils, des îlots 2,3 et 17 , du Faubourg de la porte Dauphine, de la milice et de l'occupation anglaise de 1745 à 1748, de l'administration et des casernes du bastion du Roi.

Nous avons cru utile de présenter la liste de ces travaux qui sont polycopiés et déposés au Parc Historique National de la Forteresse de Louisbourg, Nouvelle-Ecosse.

ADAMs, Blaine. King's Bastion: Guerites. 1966. 4-12 p. Appendices, cartes, figures et ill.

BAKER, Raymond F. The Siege of Louisbourg, 1745. 1966. 101 p. Appendices, cartes et bibliographie.

BARKham, Selma. Lighthouse Report. 1968. 10 p. Appendices, planches et ill.

Preliminary Report on Block 46. 1966. 7-11 p. Appendices et figures. A Summary of Information Concerning Lartigue's Houses near the Petit Etang, 1714-1758. 1967. 7 p. Appendices: documents et figures.

Bickerton, B. C. King's Bastion General Report. 1963. 21 p. Tableaux.

Bickerton, B. C. et W. CAMERon. Final Report on the Escarp Walls of the King's Bastion. 1963. 25 p. Tableaux, appendices et suppléments.

BUREAU, Pierre. The Quay in 1745.1968. 12-16 p. Plans et appendices. 1 vol. de plans et cartes.

CAMERon, W. Report on the Casemates of the King's Bastion, 1720-1758. 1964. 37-9 p. Figures.

Caron, François. Le Bastion de la Reine: Chronologie (1729-1758). [Titre anglais] : Notes and Chronology of the Queen's Bastion (1729-1758). 1964. 25 p. Figures et appendices.

Crowley, Terence A. French Colonial Administration at Louisbourg. 17131758: an Introduction. 1969. 27 p. Ill., appendices et note bibliographique.

Dunn, Brenda. Block 2, Lot G, Property of the Commissaire Ordonnateur. 1969. 51 p. Appendices : documents et cartes.

DURAND, Nicole. Etude de la population de Louisbourg, 1713-1745. 1970. 248 p. annexes. 
En Collaboration. Chateau St. Louis: Historical Reports, Series I. 1966. 33 p. Ill. Chateau St. Louis Report Number II: The Roof to 1745. sans date. 34-4 p. Figures.

King's Bastion Summary Report Number I: The Interior Revetments of the Left and Right Faces. 1965. 1-23-3 p. Figures.

King's Bastion Summary Report Number II: The Partition Walls, Vaults and the Part of the Interior Revetments in Front of the Completed Casemates. 1966. VI-44 p. 6 feuilles de graphiques.

Report on the Chateau St-Louis, Louisbourg, as a Basis for Archaeological Research. 1962. II-29 p.

ForTIER, John. Bibliography for Military Studies. 1966. 10 p.

The Demolition of 1760. 1964. 9-2 p. Figures.

King's Bastion Report Number VIII : A Survey of the Terrain of the Citadel Area Prepared for the Purposes of Archaeological Excavation. 1965. 77 p. et 65 p. d'appendices. Cartes, plans, ill. et figures.

Military Studies Number I : French Flags of the Eighteenth Century (1660-1780). 1966. 19 p. Ill., bibliographie et appendices.

Military Studies Number II : The French Infantry and its Colors. 1966. 31 p., ill., appendices.

Fortier, Márgatet. The Dauphin Bastion. $19 \overline{9} 66.151$ p. Planches et figures. Dauphin Bastion : Preliminary Report (1720-1745). 1966. 84 p. Appendices, plans et figures.

The Princess Bastion. 1966. 168 p. Bibliogr., ill., plans et appendices.

Foster, Wayne. Post Occupational History of the Old French Town of Louisbourg, 1760-1930. 1965. 190 p. Tableaux et cartes.

Preliminary Report on Block 16. sans date. 11 p. Figures.

Francis, Dilys. King's Bastion Report Number VI : Post Demolition History of the Casemates 1760-1938. 1964. 20-1-1 p. Photographies.

The Mines and Quarries of Cape Breton Island During the French Period (1713-1760). 1965. 70 p.

Hankey, Jean. The Powder Magazine and the Barracks of the Dauphin Bastion. 1968. 10 p. Appendices : documents et plans.

The King's - Queen's Curtain Wall and Outer Works. 1967. 97 p. Plans, tableaux et appendices.

Hanna, J. H. et B. C. Bickerton. Chateau St. Louis : Supplementary Summary Reports, Series I. 1965. 62 p. Tableaux.

HoAD, Linda. The Ancien Magasin and the Engineer's House. 1967. 61 p. Appendices, cartes, planches, documents et lexique.

The Boulangerie, Hangard d'Artillerie and New England Storehouse. 1967. 15 p. Appendices, documents, cartes et planches.

Couverture en bardeaux (Wood Shingles). 1968. 5 p. Appendices et bibliographie.

The Eperon. 1968. 11 p. Appendices et plans.

The Magasin du Roi. 1967. Appendices : cartes et documents.

Humphreys, John. Preliminary Historical Report : The Royal Battery. 1964. 116 p. Appendices. Accompagné d'un second volume : Plan Appendix. sans pagination. 
LAROCHelle, Johanne. Costume militaire I: habillement, équipement, armement 1712-1748. 1964. 34 p.

LavoIE, Rodrigue. Etude sur les propriétés de Louisbourg. 1965. 44 p. Tableaux et cartes.

Quai de Louisbourg: Etude sur sa construction, son usage et son histoire, de 1716 d 1760. 1965. 51 p. Figures et appendices [traduction anglaise aussi].

Laws, A. R. M. Outline Record of Various Royal Engineer's Companies. 1965. 4-5 p.

Le Goff, Tim. Artillery at Louisbourg. 1967. 123 p. et 27 p. d'appendices. Documents.

MacDonald, Robert James. Parapets - King's Bastion. 1965. 49 p. Tableaux et appendices.

McDougall Maude, Mary C. The Settlements of Isle Royale and Isle St. Jean. 1965. Sans pagination. Tableaux, cartes et appendices.

Marchant, Brenda. Block 16. 1968. 23 p. Appendices : documents et cartes.

MAYRAND, Rose Marie. Block 1. 1965. Sans pagination. Figures, tableaux, appendices et documents.

McCartney, J. R. A Preliminary Report on the Masonry Construction of the Casemates in the Ramparts of the King's Bastion. 1963. 4-5 p. The Significance of Louisbourg in French-British Imperial Rivalry (1713-1758). 1963. 38 p.

Pothier, Bernard. Preliminary Study on Blocks 2 and 17. 1966. 47 p. Appendices : figures, cartes et tableaux.

Preliminary Report of the Dauphin Bastion. Sans date. 74 p. Appendices.

Rose, Paul. Guide to the Louisbourg Archives: A Preliminary Inventory of Holdings. 1970. sans pagination.

SCHIERE, Marise. Supplementary Notes to the "Chateau St. Louis, as Built", by R. L. Way. 1966. 143. p. Compilation de documents.

Stevenson, Wendy. King's Bastion Report Number VII : Ramparts, 1717 1758. 1964. 83 p. Plans, figures, appendices et bibliographie. Supplementary Report on the Escarps of the King's Bastion, 1744-1760. 1964. 22 p. Tableaux et appendices.

ThÉrIault, Yvette. Occupation - Destination - Ameublement du Château St-Louis de Louisbourg (1720-1758). vol. I : Le Pavillon sud. 1965. III-118 p. Appendices, figures et ill.; vol. II : La Chapelle, sacristie et chambre de l'aumônier. 1965. 41 p. Appendices et ill.; vol. III : Chambres des soldats - Chambre des officiers. 1966. 31 p. Bibliographie et index; vol. IV : La Boulangerie et les fours. 1966. 13 p. Bibliographie, ill., lexique et appendices; vol. V : Corps de garde, prison et salle d'armes. 1966. 15 p. Bibliographie et appendice.

Thibault, H.-Paul. La glacière de l'îlot 17. 1968. 17 p. Appendices : documents et cartes. 
Preliminary Report on Lots $B$ and $C$ of Block 17. 1969. 15 p. Appendices : cartes.

WAY, Ronald L. Report on the Defensive Works of the King's Bastion Fortress of Louisbourg 1962. 4-36 p. Graphiques.

WAy, Ronald L. et B. W. The Chateau St. Louis, as Built, 1720-1745. 1965. III-67 p. Figure. 